\title{
Antioxidant, Cytotoxicity and Cytoprotective Potential of Extracts of Grewia Flava and Grewia Bicolor Berries
}

\author{
Kabo Masisi ${ }^{1 *}$, Riach Masamba ${ }^{1}$, Keletso Lashani ${ }^{1}$, Chunyang Li $^{2}$, Tebogo E. Kwape ${ }^{1}$, Goabaone Gaobotse \\ ${ }^{1}$ Department of Biological Sciences and Biotechnology, Faculty of Sciences, Botswana International University of Science and \\ Technology, Palapye, Botswana \\ ${ }^{2}$ Department of Nutrition and Health, Institute of Agro-product Processing, Jiangsu Academy of Agricultural Sciences, Nanjing, Jiangsu, \\ China
}

Received May 28, 2020

Reviewed October 7, 2020

Accepted March 4, 2021

*Corresponding Author

Kabo Masisi

Department of Biological Sciences and

Biotechnology, Faculty of Sciences,

Botswana International University of

Science and Technology, 10017 Boseja

Ward, Private Bag 16, Palapye, Botswana

Tel: +267-492-1885

E-mail: masisik@biust.ac.bw
Objectives: Accumulation of cellular reactive oxygen species (ROS) leads to oxidative stress. Increased production of ROS, such as superoxide anion, or a deficiency in their clearance by antioxidant defences, mediates cellular pathology. Grewia Spp fruits are a source of bioactive compounds and have notable antioxidant activity. Although the antioxidant capacity of Grewia Spp has been studied, there is very limited evidence that links the antioxidant activities of Grewia bicolor and Grewia flava to the inhibition of free radical formation associated with damage in biological systems.

Methods: This study evaluated the protective effects of Grewia bicolor and Grewia flava extracts against free radical-induced oxidative stress and the resulting cytotoxicity effect using HeLa cells. Antioxidant properties determined using 2,2-diphenyl-1-picrylhydrazyl (DPPH) and total phenolic content (TPC) assays showed significantly higher $(p<0.05)$ antioxidant activity in Grewia flava (ethanol extract) than Grewia flava (water extract) and Grewia bicolor (ethanol and water extracts).

Results: Using 3-(4,5-dimethylthiazol-2-yl)-2,5diphenyltetrazolium bromide or MTT assay, cytotoxicity results showed that extracts of Grewia bicolor and Grewia flava were less toxic to HeLa cells at tested concentrations compared to the untreated control. This confirmed the low toxicity of these edible fruits at the tested concentrations in HeLa cells. Furthermore, hydrogen peroxide $\left(\mathrm{H}_{2} \mathrm{O}_{2}\right)$-induced cell loss was effectively reduced by pre-incubating HeLa cells with Grewia bicolor and Grewia flava extracts, with Grewia flava (ethanol extract) revealing better protection.

Conclusion: The effect was speculated to be associated with the higher antioxidant activity of Grewia flava (ethanol extract). Additional studies will warrant confirmation of the mechanism of action of such effects.

Keywords: cytoprotective, reactive oxygen species, antioxidant, grewia bicolor, cytotoxicity, grewia flava

\section{INTRODUCTION}

Reactive oxygen species (ROS) have been shown to be central during the pathogenesis of several diseases including diabetes mellitus [1], aging [2] and Alzheimer's disease [3]. Normal metabolism usually leads to the formation of ROS such as superoxide and hydroxyl radicals. Hydrogen peroxide and peroxyl radicals are removed by the cellular antioxidant defense system
$[4,5]$. Increased levels of these highly reactive and unstable molecules, however, may overwhelm the antioxidant defense mechanism and cause damage to cellular lipids, proteins, and nucleic acids hence impairing cell metabolism that ultimately results in cell death [6-8]. Various diseases and disorders have been thought to be caused by this cumulative oxidative damage which causes changes in biochemical and physiological development of the cell [5]. Therefore, antioxidants, which can neu- 
tralize free radicals, may be of central importance in combating the prevalence of this disease state [9]. Dietary antioxidants from natural sources such as fruits and vegetables are of interest as increased dietary intake of these agents may lead to protection against free radical-induced diseases $[10,11]$.

Medicinal plants have been shown to be non-toxic and harmless due to their origin and long usage as traditional medicine that treat several diseases $[12,13]$. Previous research on the efficacy and safety of some medicinal plants has shown that there can be a concentration of phytochemicals that have cytotoxic, genotoxic and carcinogenic effects when these plants are used chronically [14]. The flowering plant genus Grewia is from the family Malvaceae, comprising of approximately 400 species that are widely distributed in sub-tropical and tropical regions $[15,16]$. Previously, studies have reported the use of a number of species of the genus Grewia as medicinal agents that can treat inflammation, diabetes, ulcerative colitis, and diarrhoea [17]. Some Grewia species are used traditionally as antioxidants that possess sufficient antioxidant activity to inhibit cellular damage and disease [18]. Several Grewia species also have high levels of total phenolic content, flavonoids, tannins, and anthocyanins $[19,20]$. However, there are limited studies focusing on the antioxidant activities of Grewia flava and Grewia bicolor. Therefore, we hypothesis that Grewia flava and Grewia bicolor can inhibit cellular damage and disease through their potential antioxidant activity. The aim of our study was to evaluate the possible antioxidant activity of Grewia flava and Grewia bicolor using biochemical and in vitro tests, as well as their effect on the viability of HeLa cells under induced cytotoxicity.

\section{MATERIALS AND METHODS}

\section{Materials}

Ethanol and methanol were purchased from Fisher Scientific (USA), 2,2-diphenyl-1-picrylhydrazyl (DPPH), ferulic acid, Folin-Ciocalteu's phenol reagent and gallic acid standards were purchased from Sigma-Aldrich (USA). Dimethyl sulfoxide (DMSO), 3-(4,5-dimethylthiazolyl-2)-2,5-diphenyltetrazolium bromide (MTT), fetal bovine serum (FBS), Dulbecco's modified Eagle's medium (DMEM), Dulbecco's phosphate buffered saline (PBS), penicillin/streptomycin (P/S) and Trypsin $0.05 \%$ were purchased from Thermo Scientific (USA). HeLa cells (ATCC CCL-2) were a gift from Dr. David Nkwe of the Department of Biological Sciences and Biotechnology, Botswana International
University of Science and Technology in Botswana.

\section{Plant materials}

Berries from edible Grewia flava and Grewia bicolor were collected from the Tswapong area in the Central District, Botswana. Grewia flava and Grewia bicolor were hand separated to get the peel for use throughout the study.

\section{Sample preparation}

For extraction, 700-1,000 mg of peels of the berries were macerated in $10 \mathrm{~mL}$ of deionized water or ethanol-water $(60: 40$, $\mathrm{v} / \mathrm{v})$ using mortar and pestle. They were then transferred to polyester centrifuge tubes. The tubes were vigorously shaken for $30 \mathrm{~min}$ on an orbital shaker and then centrifuged at 15,000 $\mathrm{g}$ for $10 \mathrm{~min}$. The resulting supernatant was collected. This was repeated thrice, and the solvent was evaporated under nitrogen gas in a fume hood at room temperature to produce dried pallet. Samples for biochemical assay were reconstituted with $10 \mathrm{~mL}$ ethanol. While samples for cell culture assay were reconstituted with PBS. The ethanol extracted samples were first dissolved in $1 \mathrm{~mL}$ of DMSO. Then, $9 \mathrm{~mL}$ of PBS was added to make a total volume to $10 \mathrm{~mL}$. All the samples for cell culture assay were filtered with sterile Whatman filters $(0.45 \mu \mathrm{m})$.

\section{Biochemical model}

\section{1) Total phenolic content determination}

Total phenolic content (TPC) in Grewia color and Grewia flava peel extracts was determined following modifications of the Folin-Ciocalteu method [21]. The Folin-Ciocalteu method is an electron transfer based assay that gives reducing capacity which is expressed as phenolic content. In brief, Folin-Ciocalteu's phenol reagent was diluted 10 times and $0.2 \mathrm{~mL}$ of diluted peel extracts were added to $1.5 \mathrm{~mL}$ of the Folin-Ciocalteu's phenol reagent. This was followed by the addition of $1.5 \mathrm{~mL}$ of sodium carbonate solution $(60 \mathrm{~g} / \mathrm{L})$ to the mixture. The mixture was incubated in the dark at room temperature $\left(24 \pm 1^{\circ} \mathrm{C}\right)$ for $90 \mathrm{~min}$. Absorbance was recorded at $725 \mathrm{~nm}$ with a spectrophotometer against a methanol blank and a ferulic acid ( 0 to $200 \mu \mathrm{g} / \mathrm{mL}$ ) standard. Results were expressed as milligrams of ferulic acid equivalent (FAE) per gram of sample (mg FAE/g sample). All analyses were conducted in triplicates. 


\section{2) Antioxidant activity evaluation by DPPH radical} scavenging capacity assay

Antioxidant activity was evaluated using 2,2-diphenyl1-picrylhydrazyl (DPPH) [22] with some modifications. Working DPPH solution $(60 \mu \mathrm{M})$ was freshly prepared from DPPH stock solution $(300 \mu \mathrm{M})$. Then, $3.9 \mathrm{~mL}$ of the working solution was reacted with peel extract $(100 \mu \mathrm{L})$ and incubated for 30 $\mathrm{min}$. Then, absorbance readings were taken at $515 \mathrm{~nm}$ against a blank of methanol using spectrophotometer. The analyses were conducted in triplicates. The gallic acid standard curve was made from concentrations ranging from $0-300 \mu \mathrm{g} / \mathrm{mL}$. DPPH antioxidant activity was calculated as \% DPPH radical scavenging activity as follows:

$$
\begin{aligned}
& \text { DPPH radical scavenging activity }(\%)= \\
& \quad\left(1-\left[\frac{A_{\text {sample }}-A_{\text {control }}}{A_{\text {control }}-A_{\text {blank }}}\right]\right) \times 100
\end{aligned}
$$

Where $\mathrm{A}_{\text {control }}$ is DPPH radical absorbance in methanol at 0 min, $A_{\text {sample }}$ is DPPH radical absorbance for the sample extract or standard at $30 \mathrm{~min}$. A \% DPPH decolorization calibration curve was used to quantify extracts antioxidant capacity. Gallic equivalents (GE) per gram of wet samples was representative of antioxidant capacity.

Gülçin et al. [23] explain that the DPPH assay utilizes the susceptibility of DPPH in methanol to antioxidants which can be either polar or non-polar. The radical scavenging activity of antioxidants occurs through the donation hydrogen or the donation of electrons.

\section{Cell culture assays}

\section{1) Cell line maintenance}

The present study used human adenocarcinoma (HeLa cells) to assess the in vitro effects of extracts in relation to cellular oxidation. HeLa cells were maintained and grown in DMEM with essential supplements, including $10 \%$ FBS, to provide growth promotion and $1 \% \mathrm{P} / \mathrm{S}$ to prevent bacterial contamination. Cells were grown in T-25 flasks at $37^{\circ} \mathrm{C}$ in a $5 \% \mathrm{CO}_{2}$ humidified incubator for optimal growth. In order to maintain normal cell growth, growth medium was changed twice a week. At 85-95\% confluency, cells were passaged at a sub-cultivation ratio of 1:4.

\section{2) Cytotoxicity activity}

MTT assay was used to determine the cytotoxicity of various concentrations of extracts and $\mathrm{H}_{2} \mathrm{O}_{2}$. HeLa cells were detached from T-25 flask at a density of $2 \times 10^{4}$ and were cultured in a 96-well plate $(100 \mu \mathrm{L} /$ well $)$ and maintained at $37^{\circ} \mathrm{C}$ with $5 \%$ $\mathrm{CO}_{2}$ until confluent. After that, the medium in all wells was aspirated. Hundred microliters of either extracts, control or blank were loaded into appropriate wells with PBS used for the control and blank wells. Plate was incubated for $4 \mathrm{~h}$ at room temperature. After incubating for $4 \mathrm{~h}, 10 \mu \mathrm{L}$ of MTT reagent was added to all wells except the blank wells. The plate was then incubated for $3 \mathrm{~h}$ at room temperature in the dark until the intracellular punctate purple precipitate was visible under the microscope. One hundred $\mu \mathrm{L}$ of detergent reagent was then added to all wells except the blank wells. The plate was swirled gently and incubated at $37^{\circ} \mathrm{C}$ in a $5 \% \mathrm{CO}_{2}$ humidified incubator overnight. The absorbance reading was measured at $570 \mathrm{~nm}$ using the spectrophotometer plate reader. Cytotoxicity was expressed as percentage cell viability and was determined by the comparison of the absorbances of both treated and control cells. Cell viability (\%) $=$ (absorbance of treatments) / (absorbance of controls $) \times 100 \%$. Analysis was done in triplicates.

\section{3) $\mathrm{H}_{2} \mathrm{O}_{2}$-induced cellular oxidation}

MTT assay was used to determine cytoprotection of extracts against $\mathrm{H}_{2} \mathrm{O}_{2}$-induced oxidation. Specifically, HeLa cells were cultured in a 96-well plate until they reached confluence. Then, medium in all the wells was aspirated and $100 \mu \mathrm{L}$ of different concentrations of extracts $(0.5,2,5,10,20,35 \mathrm{mg} / \mathrm{mL})$ were added to appropriate sample wells, and PBS to the control and blank wells. After incubation for $2 \mathrm{~h}, 10 \mu \mathrm{L}$ of $100 \mathrm{mM} \mathrm{H}_{2} \mathrm{O}_{2}$ was added to the sample and $\mathrm{H}_{2} \mathrm{O}_{2}$ positive control wells. Cells were incubated for another $4 \mathrm{~h}$ at room temperature. Then, MTT reagent was added to all wells except the blank wells. The plate was then incubated for $3 \mathrm{~h}$ at room temperature in the dark or until the intracellular punctate purple precipitate was visible under the microscope. Detergent reagent was then added to all wells except the blank wells. The plate was swirled gently and incubated at $37^{\circ} \mathrm{C}$ in $5 \% \mathrm{CO}_{2}$. The absorbance readings were measured at $570 \mathrm{~nm}$ using the spectrophotometer plate reader. The cytoprotective activity of extracts was represented by cell viability (\%). All analyses were done in triplicates.

\section{Statistical analysis}

Data collected was subjected to analysis of variance (ANOVA) by social survey research information (SSRI) statistical software-excel statistics. Values were presented as means \pm 
standard error (SE). Statistical significance of difference among mean values was estimated at $\mathrm{p}<0.05$ according to one-way ANOVA and Tukey-Kramer's range test. Some data underwent regression analysis, and the correlation coefficient was calculated.

\section{RESULTS}

\section{Biochemical assays}

\section{1) Total phenolic content activity}

Folin-Ciocalteu assay was used to determine TPC of extracts from Grewia bicolor and Grewia flava by constructing a standard curve with ferulic acid (FA) which took into consideration the relationship between absorbance and concentration. The calibration curve generated from analysis of the standard (ferulic acid) was linear with $\mathrm{y}=0.005 \mathrm{x}+0.0275 ; \mathrm{R}^{2}=0.9988$.

Grewia flava was found to have the highest phenolic content followed by the water extract (Grewia bicolor and Grewia flava). Ethanol extract (Grewia bicolor) showed the lowest content (Fig. 1). The final TPC was expressed as millimolar of ferulic acid equivalent per mg of Grewia bicolor and Grewia flava.

\section{2) DPPH activity}

Percentage scavenging effect of the extracts from Grewia bicolor and Grewia flava were determined using DPPH assay

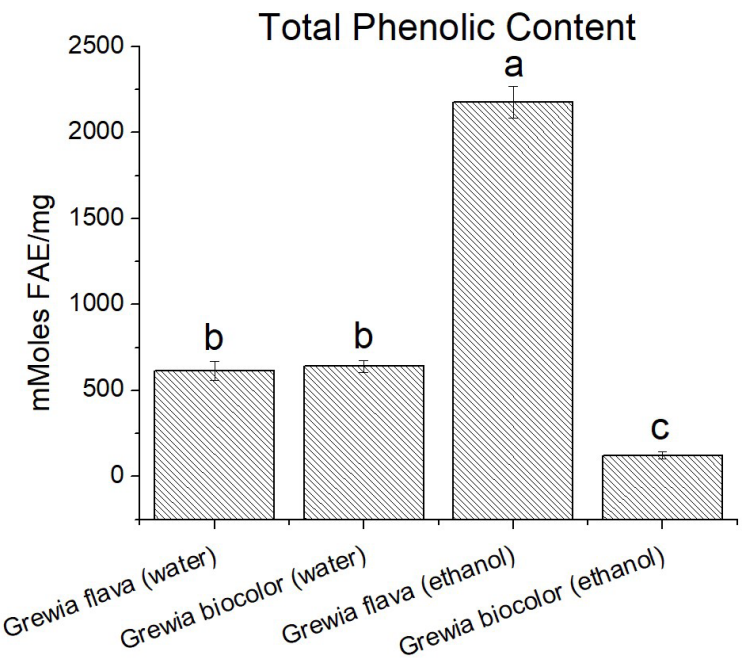

Figure 1. The total phenolic content (mM ferulic acid equivalent) per $0.7 \mathrm{~g}$ of wet samples of ethanolic extract and water extracts of Grewia flava and Grewia bicolor and standards by TPC method. Values are mean \pm standard error $(n=3)$. Significant differences among the extracts are indicated by different letters $(p<0.05$, Tukey-Kramer's range test). through the construction of a standard curve with Gallic acid (GA), which took into consideration the relationship between absorbance and concentration. A linear calibration curve was produced from the analysis of gallic acid (standard) with $\mathrm{y}=$ $0.0007 x+0.246 ; R^{2}=0.9975$.

Grewia flava was shown to have the highest DPPH scavenging capacity followed by water extract (Grewia flava) and ethanol extract (Grewia bicolor). Water extract (Grewia bicolor) showed the lowest scavenging capacity (Fig. 2). The final DPPH scavenging capacity was expressed as micromolar of gallic acid equivalent per mg of the Grewia bicolor and Grewia flava.

\section{Cell culture assays}

\section{1) Cytotoxicity of hydrogen peroxide and extracts}

The cytotoxicity assay confirms if the sample treatments had a negative effect on the viability of cells. To determine the cytotoxicity effect of hydrogen peroxide $\left(\mathrm{H}_{2} \mathrm{O}_{2}\right)$, Grewia bicolor and Grewia flava were evaluated with MTT cell viability assay. Confluent cells were incubated with $\mathrm{H}_{2} \mathrm{O}_{2}$ concentrations of 0 , $1,5,10,50$ and $100 \mathrm{mM}$ that were prepared in PBS. An escalating concentration of $\mathrm{H}_{2} \mathrm{O}_{2}$ from 0 to $100 \mathrm{mM}$ promoted the increasing loss of HeLa cells. After $4 \mathrm{~h}$ of treatment with $\mathrm{H}_{2} \mathrm{O}_{2}$, $48-80 \%$ of cell viability was observed (Fig. 3). When Compared to untreated control (the control $=100 \%$ viability) extracts were not toxic to the cells (63-93\% live cells; Fig. 4-7). To be consid-

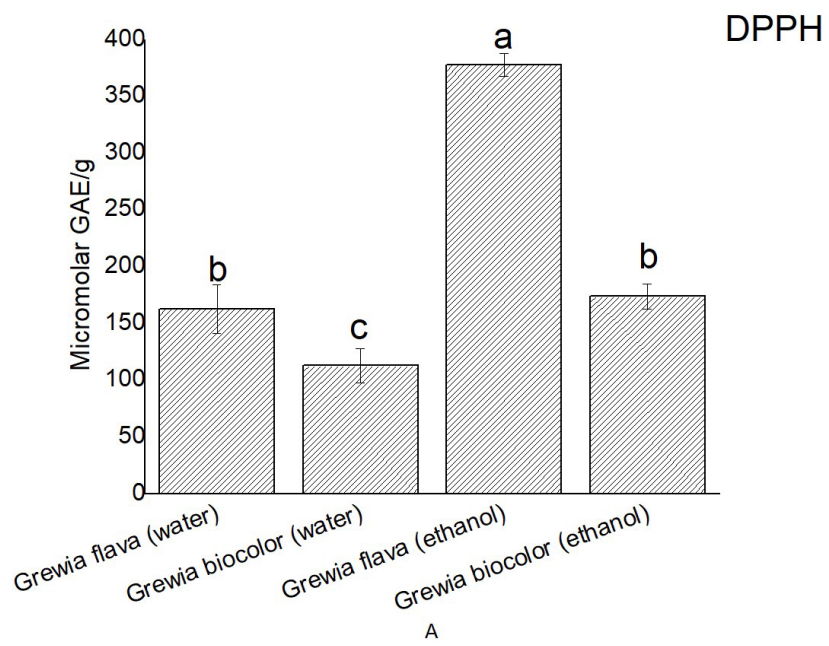

Figure 2. DPPH scavenging activity ( $\mu \mathrm{M}$ gallic acid equivalent) per $0.7 \mathrm{~g}$ of wet samples of ethanolic extract and water extracts of Grewia flava and Grewia bicolor and standards by DPPH method. Values are mean \pm standard error $(n=3)$. Significant differences among the extracts are indicated by different letters $(p<0.05$, Tukey-Kramer's range test). 


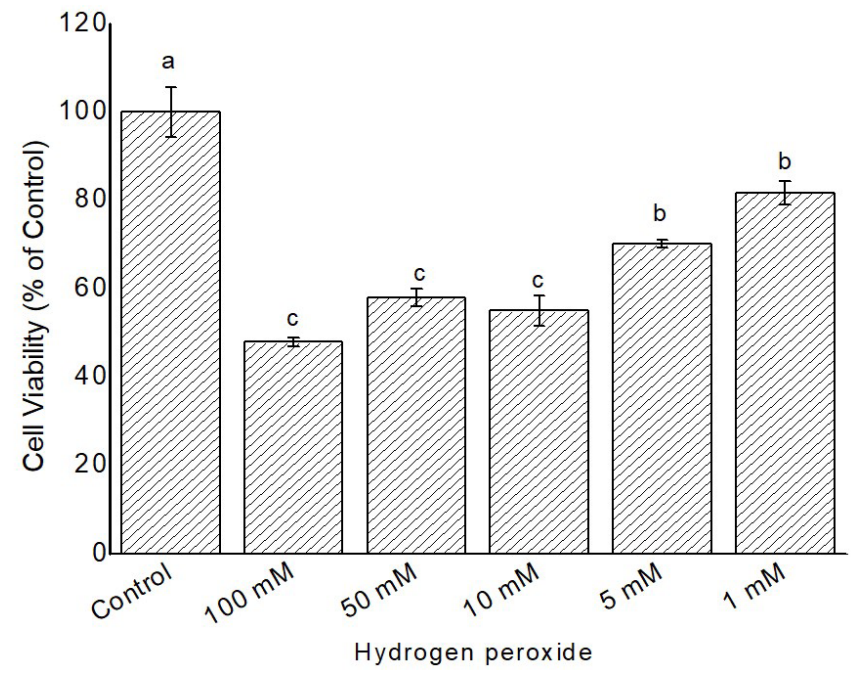

Figure 3. Cytotoxicity induced by $\mathrm{H}_{2} \mathrm{O}_{2}$ at 1 to $100 \mathrm{mM}$ in confluent HeLa cells was measured by MTT assay. Untreated cells at $100 \%$ cell viability were the control. Values are mean \pm standard error $(n=3)$. Significant differences among the concentrations are indicated by different letters ( $p<0.05$, Tukey-Kramer's range test).

\section{Grewia bicolor-Water Extract}

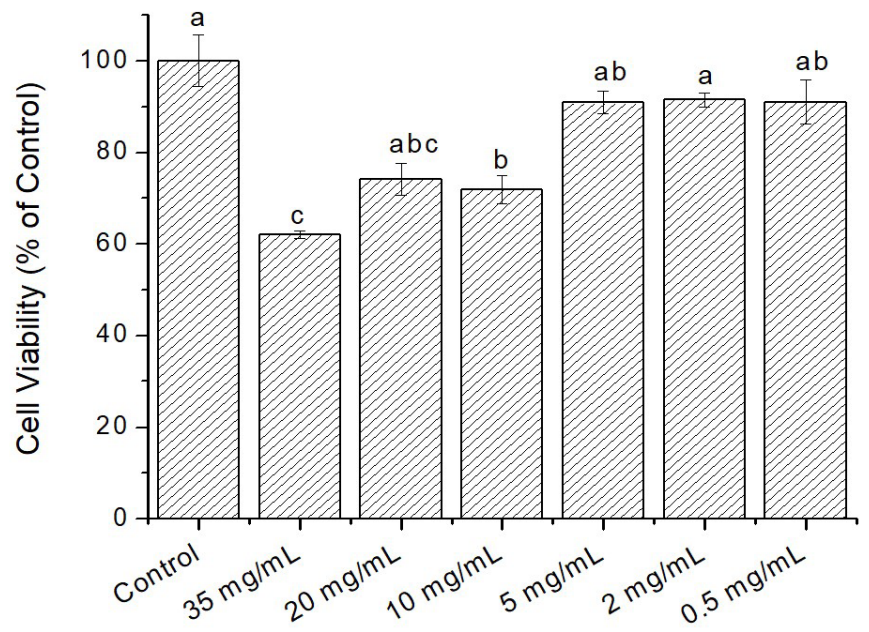

Figure 4. Cytotoxicity of Grewia bicolor extracts (water extracts) at 0 to $35 \mathrm{mg} / \mathrm{mL}$ in confluent HeLa cells determined by MTT assay. Untreated cells at $100 \%$ cell viability were the control. Values are mean \pm standard error $(n=3)$. Significant differences among the concentrations are indicated by different letters $(p<0.05$, Tukey-Kramer's range test).

ered toxic, an extract should be lethal to $50 \%$ of the organism exposed to it during a toxic test. Based on toxicity levels, 2 and $10 \mathrm{mg} / \mathrm{mL}$ were selected to be tested on $100 \mathrm{mM}$ of $\mathrm{H}_{2} \mathrm{O}_{2}$ to stimulate oxidation.
Grewia bicolor-Ethanol: water (60:40) Extraction

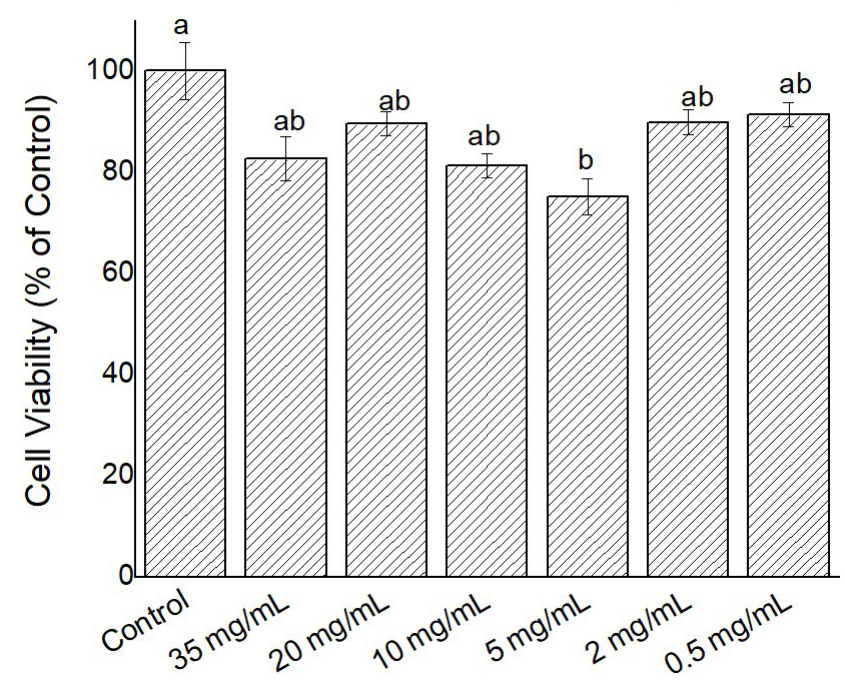

Figure 5. Cytotoxicity of Grewia bicolor extracts (ethanol, 60: water, 40 extracts) at 0 to $35 \mathrm{mg} / \mathrm{mL}$ in confluent HeLa cells determined by MTT assay. Untreated cells at $100 \%$ cell viability were the control. Values are mean \pm standard error $(n=3)$. Significant differences among the concentrations are indicated by different letters ( $p<0.05$, TukeyKramer's range test).

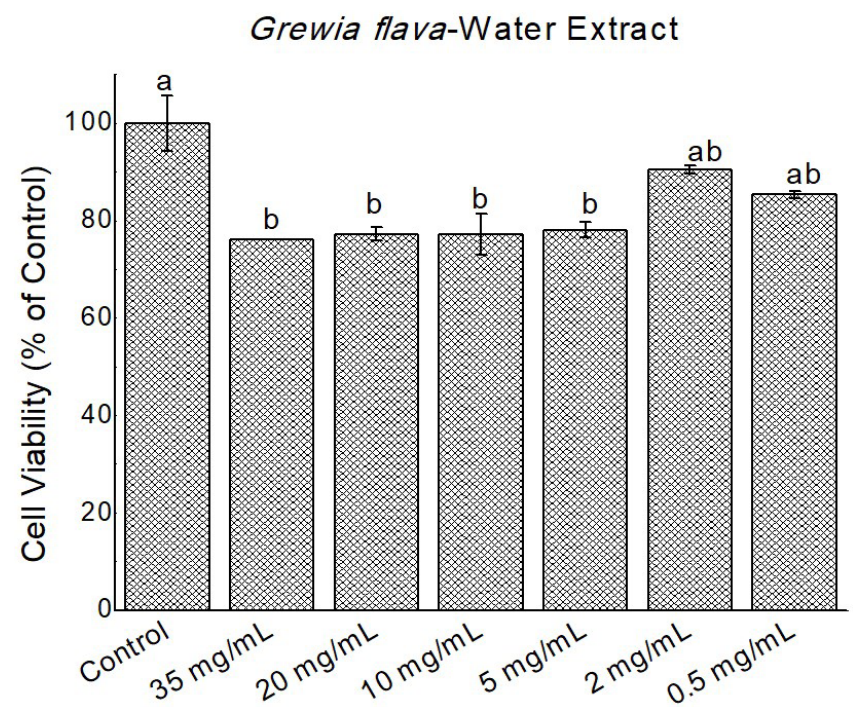

Figure 6. Cytotoxicity of Grewia flava extracts (water extracts) at 0 to $35 \mathrm{mg} / \mathrm{mL}$ in confluent HeLa cells determined by MTT assay. Untreated cells at $100 \%$ cell viability were the control. Values are mean \pm standard error $(n=3)$. Significant differences among the concentrations are indicated by different letters $(p<0.05$, Tukey-Kramer's range test).

\section{2) Cytoprotective activity against $\mathrm{H}_{2} \mathrm{O}_{2}$}

Using the findings of cytotoxicity testing, 2 , and $10 \mathrm{mg} / \mathrm{mL}$ of extracts were applied against $100 \mathrm{mM} \mathrm{H}_{2} \mathrm{O}_{2}$-induced oxida- 




Figure 7. Cytotoxicity of Grewia flava extracts (ethanol, 60: water, 40 extracts) at 0 to $35 \mathrm{mg} / \mathrm{mL}$ in confluent HeLa cells determined by MTT assay. Untreated cells at $100 \%$ cell viability were the control. Values are mean \pm standard error $(n=3)$. Significant differences among the concentrations are indicated by different letters $(p<0.05$, TukeyKramer's range test).

tive damage in HeLa cells. Our results indicate that different extracts and concentration affected cell viability differently. Cellular viability ranged from $68-86 \%$ (Fig. 8, 9). All extracts were able to protect the cells from $\mathrm{H}_{2} \mathrm{O}_{2}$ initiated oxidation damage except Grewia bicolor (10 mg/mL water extract) (Fig. 8). Ethanol extract showed better protection as compared to water extracts.

\section{DISCUSSION}

Free radicals are the major causes of oxidative stress related disorders. Human diet comprising of bioactive compounds from plants is reported to offer antioxidant protection against oxidative stress-induced cellular damage associated with several chronic diseases [24].

In this study, Grewia bicolor and Grewia flava were selected to study their potential antioxidant protection ability and cytotoxicity activity. The study was performed using berries, ethanol and water extracts. Antioxidants play an important role in providing defence against oxidative damage because of their property of scavenging radicals. Antioxidant activity was determined by TPC and DPPH methods. TPC was determined by Folin-Ciocalteu assay with the principle that the reaction

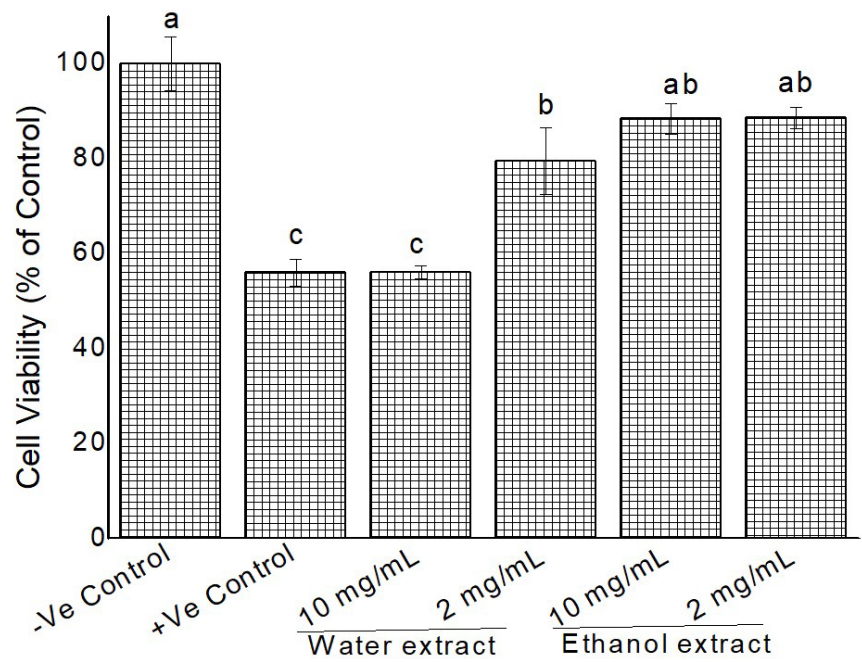

Figure 8. Cytoprotective activity of Grewia bicolor extracts against $\mathrm{H}_{2} \mathrm{O}_{2}$ induced oxidation (100 mM) in confluent HeLa cells measured by MTT assay. Negative control were untreated cells at $100 \%$ cell viability and positive control was treated cells with $100 \mathrm{mM} \mathrm{H}_{2} \mathrm{O}_{2}$. Values are mean \pm standard error $(n=3)$. Significant differences among the concentrations are indicated by different letters $(p<0.05$, TukeyKramer's range test).



Figure 9. Cytoprotective activity of Grewia flava extracts against $\mathrm{H}_{2} \mathrm{O}_{2}$ induced oxidation $(100 \mathrm{mM})$ in confluent HeLa cells measured by MTT assay. Negative control were untreated cells at $100 \%$ cell viability and positive control was treated cells with $100 \mathrm{mM} \mathrm{H}_{2} \mathrm{O}_{2}$. Values are mean \pm standard error $(n=3)$. Significant differences among the concentrations are indicated by different letters $(p<0.05$, Tukey-Kramer's range test).

between phenolic compounds and Folin-Ciocalteu reagent produces a blue colored complex. The resulting color is proportional to the number of reacting phenolic hydroxyl group and is quantified using a spectrophotometer [25]. In this study, TPC 
was estimated with ferulic acid as a standard and showed highest content with ethanol extract (Grewia flava) followed by water extract (Grewia bicolor and Grewia flava). Similar findings were reported by other researchers that showed that ethanol extracts possess significantly higher TPC content than water and other solvents [26-28]. Surprisingly, the lowest TPC was observed with ethanol extract (Grewia bicolor). Further studies are necessary to confirm this observation.

$\mathrm{DPPH}$ assay is used widely to evaluate antioxidant activity. This method determines the activity of the sample against the stable organic nitrogen radical DPPH [25]. The nitrogen radical in DPPH is quenched by an antioxidant to yield a yellow color complex [22]. Consistent with TPC, DPPH assay demonstrated the highest DPPH free radical quenching activity with ethanol extract (Grewia bicolor and Grewia flava) followed by water extract (Grewia bicolor and Grewia flava). Similar findings have been reported showing that ethanol extracts possess significantly higher DPPH content than water and other solvents [2628].

Cytotoxicity assays measure the toxicity of a treatment on the cells. Here, we evaluated the cytotoxic effects of peel extracts of Grewia bicolor and Grewia flava with MTT assay. The water-soluble yellow colored MTT reagent decomposes to water insoluble purple formazan when incubated with live cells. Dead cells do not have this ability. In this study, the effect of the extracts on cell viability at concentrations from $0.5,2,5,10,20$ and $35 \mathrm{mg} / \mathrm{mL}$ were tested on HeLa cells. The results show that the extracts of Grewia bicolor and Grewia flava are less toxic (high cell viability) on HeLa cells at the tested concentrations when compared to the control. This confirms the safety of the use of these edible plants.

Hydrogen peroxide is a reactive oxygen species which can initiateradicals that can destroy certain biological molecules, cause cellular damage and lead to pathogenesis [29]. $\mathrm{H}_{2} \mathrm{O}_{2}$ experiments are important in the study of antioxidants. In this study, all extracts were able to protect the cells from $\mathrm{H}_{2} \mathrm{O}_{2}$ induced oxidation damage except Grewia bicolor $(10 \mathrm{mg} / \mathrm{mL}$ water extract). According to Elisa \& Kitts [30], reduction of human cell viability induced by $\mathrm{H}_{2} \mathrm{O}_{2}$ is in part to apoptosis activated by $\mathrm{H}_{2} \mathrm{O}_{2}$. Due to thermal decomposition, $\mathrm{H}_{2} \mathrm{O}_{2}$ lead to the production of peroxyl radicals in cells in culture. As these peroxyl radicals accumulate intracellularly, there is promotion of lipid peroxidation, cell membrane damage also occurs, and ultimately cell apoptosis occurs [31]. In the present study, specific concentrations of extract showed effectiveness in reduc- ing cell loss due to the effect of $\mathrm{H}_{2} \mathrm{O}_{2}$. Therefore, our findings suggest that ethanol extracts (Grewia bicolor and Grewia flava) may function as free radical cleaners that promote cell viability by reducing ROS and preventing the formation of apoptotic cells caused by $\mathrm{H}_{2} \mathrm{O}_{2}$ oxidation.

\section{CONCLUSION}

Our study has shown that indigenous edible plants Grewia bicolor and Grewia flava are non-toxic at the tested concentrations. Furthermore, our results indicate that ethanol extract of Grewia flava has strong cytoprotective effect against $\mathrm{H}_{2} \mathrm{O}_{2}$ initiated loss of cell viability which can be attributed to the high antioxidant activity of this extract.

\section{ACKNOWLEDGEMENT}

We would like to thank Botswana International University of Science and Technology, Department of Biological Sciences and Biotechnology for providing infrastructure and facilitating the performance of this study.

\section{CONFLICTS OF INTEREST}

All authors declare no conflict of interest.

\section{FUNDING}

This research work was funded by an initiation grant from the Botswana International University of Science and Technology.

\section{ORCID}

Kabo Masisi, https://orcid.org/0000-0001-7128-6999

Riach Masamba, https://orcid.org/0000-0003-2792-5444

Keletso Lashani, https://orcid.org/0000-0002-9913-5014

Chunyang Li, https://orcid.org/0000-0002-1180-0869

Tebogo E. Kwape, https://orcid.org/0000-0001-5015-6888

Goabaone Gaobotse, https://orcid.org/0000-0003-2174-2823

\section{REFERENCES}

1. Hayakawa M, Kuzuya F. [Free radicals and diabetes mellitus]. Nihon Ronen Igakkai Zasshi. 1990;27(2):149-54. Japanese. 
2. Meydani M, Lipman RD, Han SN, Wu D, Beharka A, Martin $\mathrm{KR}$, et al. The effect of long-term dietary supplementation with antioxidants. Ann N Y Acad Sci. 1998;854(1):352-60.

3. Simonian NA, Coyle JT. Oxidative stress in neurodegenerative diseases. Annu Rev Pharmacol Toxicol. 1996;36:83-106.

4. Halliwell B, Gutteridge JM. The definition and measurement of antioxidants in biological systems. Free Radic Biol Med. 1995; 18(1):125-6.

5. Wang SY, Jiao H. Scavenging capacity of berry crops on superoxide radicals, hydrogen peroxide, hydroxyl radicals, and singlet oxygen. J Agric Food Chem. 2000;48(11):5677-84.

6. Packer L. Antioxidant defences in biological systems: an overview. In: Packer L, Traber MG, Xin W, editors. Proceedings of the International Symposium on Natural Antioxidants: molecular mechanisms and health effects. Champaign (IL): AOCS Press; 1996. p. 9-44.

7. Poli G, Leonarduzzi G, Biasi F, Chiarpotto E. Oxidative stress and cell signalling. Curr Med Chem. 2004;11(9):1163-82.

8. Stadtman ER. Protein modification in oxidative stress. In: Paoletti R, editor. Oxidative processes and antioxidants. New York (NY): Raven Press; 1994. p. 117-34.

9. Wang H, Cao G, Prior RL. Total antioxidant capacity of fruits. J Agric Food Chem. 1996;44(3):701-5.

10. Doll R. An overview of the epidemiological evidence linking diet and cancer. Proc Nutr Soc. 1990;49(2):119-31.

11. Gey KF. The antioxidant hypothesis of cardiovascular disease: epidemiology and mechanisms. Biochem Soc Trans. 1990;18(6): 1041-5.

12. Chen XW, Serag ES, Sneed KB, Zhou SF. Herbal bioactivation, molecular targets and the toxicity relevance. Chem Biol Interact. 2011;192(3):161-76.

13. Fennell CW, Lindsey KL, McGaw LJ, Sparg SG, Stafford GI, Elgorashi EE, et al. Assessing African medicinal plants for efficacy and safety: pharmacological screening and toxicology. J Ethnopharmacol. 2004;94(2-3):205-17.

14. Ernst E. Risks of herbal medicinal products. Pharmacoepidemiol Drug Saf. 2004;13(11):767-71.

15. Ullah W, Uddin G, Siddiqui BS. Ethnic uses, pharmacological and phytochemical profile of genus Grewia. J Asian Nat Prod Res. 2012;14(2):186-95.

16. Leistner OA. Seed plants of Southern Africa: families and genera. Pretoria: National Botanical Institute; 2000. 775 p.

17. Curtis B, Mannheimer C. Tree atlas of Namibia. Windhoek: National Botanical Research Institute; 2005. p. 432-33.

18. Kirtikar KR, Basu BD, Blatter E. Indian medicinal plants. 2nd ed. Dehradun: International Books Distributors; 1987. p. 173032.
19. Asghar MN, Khan IU, Sherin L, Ashfaq M. Evaulation of antioxidant activity of Grewia asiatica berry using 2,2'-azinobis-(3ethylbenzothiazoline-6-sulphonic acid) and N,N-dimethyl-pphenylenediamine radical cations decolourization assays. Asian J Chem. 2008;20(7):5123-32.

20. Ramshankar YV, Vinay P, Vijayan P. Antioxidant, antimicrobial and cytotoxicity properties of the methanolic extract from Grewia tiliaefolia Vahl. Pharmacogn Mag. 2008;4(16):329-34.

21. Singleton VL, Rossi JA. Colorimetry of total phenolics with phosphomolybdic-phosphotungstic acid reagents. Am J Enol Vitic. 1965;16(3):144-58.

22. Brand-Williams W, Cuvelier ME, Berset C. Use of a free radical method to evaluate antioxidant activity. LWT- Food Sci Technol. 1995;28(1):25-30.

23. Gülçin I, Elias R, Gepdiremen A, Boyer L. Antioxidant activity of lignans from fringe tree (Chionanthus virginicus L.). Eur Food Res Technol. 2006;223(6):759-67.

24. Del Rio D, Rodriguez-Mateos A, Spencer JP, Tognolini M, Borges G, Crozier A. Dietary (poly)phenolics in human health: structures, bioavailability, and evidence of protective effects against chronic diseases. Antioxid Redox Signal. 2013;18(14):1818-92.

25. Karadag A, Ozcelik B, Saner S. Review of methods to determine antioxidant capacities. Food Anal Methods. 2009;2(1):41-60.

26. Goswami S, Jain R, Masih H. Antifungal, antioxidant and DNA protection potential of Grewia asiatica L. leaves acetone extract. J Pharmacogn Phytochem. 2018;7 Suppl 1:212-7.

27. Lamola SM, Dzoyem JP, Botha F, van Wyk C. Anti-bacterial, free radical scavenging activity and cytotoxicity of acetone extracts of Grewia flava. Afr Health Sci. 2017;17(3):790-6.

28. Noreen H, Semmar N, Farman M, McCullagh JSO. Measurement of total phenolic content and antioxidant activity of aerial parts of medicinal plant Coronopus didymus. Asian Pac J Trop Med. 2017;10(8):792-801.

29. Yokozawa T, Cho EJ, Hara Y, Kitani K. Antioxidative activity of green tea treated with radical initiator 2, 2'-azobis(2-amidinopropane) dihydrochloride. J Agric Food Chem. 2000;48(10): 5068-73.

30. Elisia I, Kitts DD. Anthocyanins inhibit peroxyl radical-induced apoptosis in Caco-2 cells. Mol Cell Biochem. 2008;312(1-2):13945.

31. Kulkarni AP, Pal JK, Devasagayam TPA. Radiation and free radical exposure and regulation of protein synthesis by the heme-regulated eukaryotic initiation factor $2 \alpha$ kinase [Internet]. Mumbai: Bhabha Atomic Research Centre (BARC); 2008 [cited 2019 Aug 7]. Available from: http://barc.gov.in/publications/nl/ 2008/20081010.pdf. 